\title{
An Overview of Hydrogen as an Alternative Fuel
}

\author{
Created by: Maher Al-baghdadi ${ }^{1}$
}

1, Kufa Centre for Advanced Simulation in Engineering (KCASE), Department of Mechanical Engineering, Faculty of Engineering, University of Kufa, Iraq.; mahirar.albaghdadi@uokufa.edu.iq

Version received: 7 June 2020

check for

updates

\begin{abstract}
Hydrogen is a very important fuel of our secure and clean energy future. Hydrogen will be the fuel of the future and gradually it will replace all current fossil fuels. Hydrogen can be used as a fuel for vehicles, to heat homes and offices, to produce electricity, and to fuel ships and aircraft. The present work provides an overview of hydrogen as an alternative fuel, which can be used in internal combustion engines and in fuel cells.
\end{abstract}

\section{Hydrogen Fuel}

Hydrogen is abundant, being the most common element in the universe. The sun consumes 600 million tons of it each second. But unlike oil, large reservoirs of hydrogen are not to be found on earth. The hydrogen atoms are bound together in molecules with other elements, and it takes energy to extract the hydrogen so it can be used for combustion or fuel cells. Hydrogen is not a primary energy source, but it can be viewed as a means of exchange for getting energy to where it is needed, much like electricity. Hydrogen is a sustainable, non-polluting source of power that could be used in mobile and stationary applications. As an energy carrier, it could increase our energy diversity and security by reducing our dependence on hydrocarbon-based fuels. Although hydrogen is the simplest element and most plentiful gas in the universe, it never occurs by itself but is always combined with other elements such as oxygen and carbon. But once it has been separated, hydrogen is an extremely clean energy carrier [1]]. Hydrogen can be extracted from fossil fuels and biomass, from water, or from a mix of both.

\section{Hydrogen Fuel Storage Systems}

Hydrogen as an energy carrier must be stored to overcome daily and seasonal discrepancies between energy source availability and demand. Hydrogen can be stored physically as either a gas or a liquid. Storage of hydrogen as a gas typically requires high-pressure tanks (350-700 bar [5,000-10,000 psi] tank pressure). Storage of hydrogen as a liquid requires cryogenic temperatures because the boiling point of hydrogen at one atmosphere pressure is $\left(-252.8^{\circ} \mathrm{C}\right)$. Hydrogen can also be stored on the surfaces of solids (by adsorption) or within solids (by absorption) [1]].

The most commonly used method for hydrogen storage in fuel cell vehicles is compressed hydrogen tanks. Several vehicles (e.g. Honda FCV, Toyota FCV, Mercedes-Benz F-Cell, Hyundai FCV, and GM FCV) with such tanks are already in use today. The most important consideration for compressed gas is the material composing the tank. It must be lightweight, inexpensive and sufficiently strong to meet the required stress, strain and safety specifications. In addition, thermal conductivity of the material must be high enough to manage exothermic heat during filling the tank.

When hydrogen is stored as liquid at $1 \mathrm{~atm}$, it must be maintained below its boiling point $\left(-252.8^{\circ} \mathrm{C}\right)$. Therefore, effective thermal insulation is essential to maximize the efficiency of the liquid hydrogen tank. Therefore, typical liquid hydrogen tanks consist of metallic double-walled container, where the 
inner and outer walls are separated by vacuum for thermal insulation purposes. Despite improved volumetric density, liquid hydrogen storage is not frequently used for several reasons. One of main issues is hydrogen boil-off. The liquid hydrogen can evaporate even with highly insulated tank, which causes hydrogen loss. In addition, the boil-off occurs even when the system is dormant and increases the pressure of the tank which must be vented to prevent rupture. Apart from cost and energy efficiency penalty due to hydrogen loss, the boil-off also presents safety concerns, particularly for vehicles parked in confined space such as containers and parking garages. Second, 30-35\% of energy value of hydrogen is required to liquefy it, which is about 3 times larger than needed for compressed $\mathrm{H}_{2}$ tank []] .

As noted above, compressed tank requires a relatively large volume while liquid hydrogen can vaporize to cause loss of hydrogen as well as safety concerns. Consequently, studies of physical hydrogen storage have currently shifted to cryo-compressed $\mathrm{H}_{2}$, which combines compression and cryogenic storage. The volumetric density of hydrogen can be increased by pressurizing liquid hydrogen at $20 \mathrm{~K}$ from $70 \mathrm{~g} / \mathrm{L}$ at 1 bar to $87 \mathrm{~g} / \mathrm{L}$ at 240 bars, which reduces the requirement for expensive carbon fibre composite. In addition, it can decrease evaporative loss of hydrogen as well as extend the dormancy period in insulated pressure vessels []․

Metal hydride tank is a container loading with hydrogen storage alloy powder, heat exchange parts, and gas transport components. The container body materials are generally aluminium alloy or stainless steel. Hydrogen is stored in the form of so-called "metal hydride". Most metals or alloys can react with hydrogen to form new compounds, which are named as metal hydrides. The formation of metal hydride is an exothermic process associated with heat releasing. With sufficient heat supply, hydrogen can be released from the as-formed metal hydride. Some metal hydrides have the potential for reversible onboard hydrogen storage and release hydrogen at the relatively low temperatures and pressures required for fuel cells [1]].

As compared to conventional metal hydrides, complex metal hydrides offer the potential to improve gravimetric hydrogen capacity. However, complex metal hydrides still provide relatively low hydrogen capacity and slow hydrogen uptake and release kinetics. Many different types of metal hydrides have been studied as means of hydrogen storage. However, superior hydrogen release properties (yield and kinetics) are obtained at temperatures much higher than PEM fuel cell operation conditions.

High surface area sorbents based on metal-organic frameworks have been considered as promising materials for hydrogen storage ever due to their high porosity and controllable structural characteristics. The metal-organic frame works are crystalline and micro porous solids composed of metal ions or clusters linked with organic molecules and typically have surface area greater than $3000 \mathrm{~m}^{2} / \mathrm{g}$. Despite reversible nature of the hydrogen absorption/desorption process for high surface area sorbents and carbon-based materials, they suffer from lower hydrogen capacity, especially under mild operating conditions.

As compared to metal hydrides, chemical hydrides offer higher energy densities since they contain lighter elements. In addition, they can release hydrogen under relatively mild operating conditions. The dehydrogenation reactions, however, are irreversible, so the resulting products have to be regenerated off-board the vehicle.

In conclusion, although hydrogen has high gravimetric energy density, its volumetric energy density is poor, which presents a significant barrier for use of hydrogen on-board fuel cell vehicles. Current approaches for on-board hydrogen storage include compressed hydrogen gas, cryogenic and liquid hydrogen, sorbents, metal hydrides, and chemical hydrides. The advantages and disadvantages for each approach are summarized in Table 1.

Technologies for hydrogen conversion into other useful energy forms have already been developed and demonstrated. In almost all cases hydrogen is converted more efficiently than any other fuel, and more 
important, hydrogen conversion creates little or no emissions (mainly water or water vapor). These technologies are the driving force for development of technologies for hydrogen production and storage [2].

Table 1. Advantages and disadvantages of different hydrogen storage approaches ${ }^{[1]}$.

\begin{tabular}{|c|c|c|}
\hline $\mathrm{H}_{2}$ storage system & Advantages & Disadvantages \\
\hline Compressed $\mathrm{H}_{2}$ & - Commercially available. & $\begin{array}{l}\text { - Low volumetric capacity. } \\
\text { - High compression energy. } \\
\text { - Heat management during charging required. }\end{array}$ \\
\hline Liquid $\mathrm{H}_{2}$ & - Commercially available. & $\begin{array}{l}\text { - } \mathrm{H}_{2} \text { loss. } \\
\text { - Safety issue. } \\
\text { - High liquefaction energy. } \\
\text { - Heat management to reduce boil-off. }\end{array}$ \\
\hline Cryo-compressed & - High volumetric capacity. & - High compression/liquefaction energy. \\
\hline Metal hydride & - Reversible on-board. & $\begin{array}{l}\text { - Low gravimetric/volumetric capacity. } \\
\text { - Heat management during charging required. } \\
\text { - High operating temperature for } \mathrm{H}_{2} \text { release. }\end{array}$ \\
\hline $\begin{array}{l}\text { Sorbent and carbon- } \\
\text { based materials }\end{array}$ & - Reversible on-board. & $\begin{array}{l}\text { - Low volumetric density. } \\
\text { - Loss of useable } \mathrm{H} 2 \text {. } \\
\text { - Low operating temperature for } \mathrm{H}_{2} \text { uptake. }\end{array}$ \\
\hline Chemical hydride & $\begin{array}{l}\text { - Good volumetric capacity. } \\
\text { - Proper operating temperatures. }\end{array}$ & $\begin{array}{l}\text { - Thermal management required. } \\
\text { - Off-board regeneration. }\end{array}$ \\
\hline
\end{tabular}

\section{Safety Aspects of Hydrogen as Fuel}

Like any other fuel or energy carrier, hydrogen poses risks if not properly handled or controlled. The risk of hydrogen, therefore, must be considered relative to the common fuels such as gasoline, alcohol, propane, or natural gas. The specific physical characteristics of hydrogen are quite different from those common fuels. Some of these properties make hydrogen potentially less hazardous, whereas other hydrogen characteristics could theoretically make it more dangerous in certain situations. Because hydrogen has the smallest molecule, it has a greater tendency to escape through small openings than other liquid or gaseous fuels. If a leak should occur for whatever reason, hydrogen will disperse much faster than any other fuel, thus reducing the hazard levels. Hydrogen is both more buoyant and more diffusive than gasoline, propane, or natural gas []ㅡ.

Hydrogen/air mixture can burn in relatively wide volume ratios, between $4 \%$ and $75 \%$ of hydrogen in air. Other fuels have much lower flammability ranges, viz., natural gas 5.3-15\%, propane $2.1-10 \%$, and gasoline $1-7.8 \%$. However, this range has little practical value. In many actual leak situations the key parameter that determines if a leak would ignite is the lower flammability limit, and hydrogen's lower 
flammability limit is 4 times higher than that of gasoline, 1.9 times higher than that of propane, and slightly lower than that of natural gas []․

Hydrogen has a very low ignition energy $(0.02 \mathrm{mj})$, about one order of magnitude lower than other fuels. Ignition energy is a function of the fuel/air ratio, and for hydrogen it reaches a minimum at about 25-30\% hydrogen content in air. At the lower flammability limit (LFL), hydrogen ignition energy is comparable to that of natural gas $[\underline{3}]$.

Hydrogen has a flame velocity 7 times faster than that of natural gas or gasoline. A hydrogen flame would therefore be more likely to progress to a deflagration or even a detonation than other fuels. However, the likelihood of a detonation depends in a complex manner on the exact fuel/air ratio, the temperature, and particularly the geometry of the confined space. Hydrogen detonation in open atmosphere is highly unlikely.

The lower detonability fuel/air ratio for hydrogen is $13-18 \%$, which is two times higher than that of natural gas and 12 times higher than that of gasoline. Because the lower flammability limit is $4 \%$, an explosion is possible only under the most unusual scenarios, for example, hydrogen would first have to accumulate and reach $13 \%$ concentration in a closed space without ignition, and at that point an ignition source would have to be triggered. Should an explosion occur, hydrogen has the lowest explosive energy per unit of stored energy of any fuel, and a given volume of hydrogen would have 22 times less explosive energy than the same volume filled with gasoline vapor ${ }^{[} \underline{]}$.

Hydrogen flame is nearly invisible, which may be dangerous, because people in the vicinity of a hydrogen flame may not even realize there is a fire. This may be remedied by adding chemicals that will provide the necessary luminosity. The low emissivity of hydrogen flames means that nearby materials and people will be much less likely to ignite or be hurt by radiant heat transfer. The fumes and soot from a gasoline fire pose a risk to anyone inhaling the smoke, whereas hydrogen fires produce only water vapor (unless secondary materials begin to burn).

Liquid hydrogen presents another set of safety issues, such as risk of cold burns, and the increased duration of leaked cryogenic fuel. A large spill of liquid hydrogen has some characteristics of a gasoline spill; however, it will dissipate much faster. Another potential danger is a violent explosion of a boiling liquid expanding vapor in case of a pressure relief valve failure.

Hydrogen on-board a vehicle may pose a safety hazard. Such hazards should be considered in situations when the vehicle is inoperable, when the vehicle is in normal operation, and in collisions. Usually, potential hazards are due to fire, explosion, or toxicity. The latter can be ignored, because neither hydrogen nor its fumes in case of fire are toxic. Hydrogen as a source of fire or explosion may come from the fuel storage, from the fuel supply lines, or from the fuel cell itself. The fuel cell poses the least hazard, although in a fuel cell hydrogen and oxygen are separated by a very thin polymer membrane. In case of membrane rupture hydrogen and oxygen would combine, and the fuel cell would immediately lose its potential, which should be easily detected by a control system. In such a case the supply lines would be immediately disconnected.

In conclusion, hydrogen appears to pose risks of the same order of magnitude as other fuels. In spite of public perception, in many aspects hydrogen is actually a safer fuel than gasoline and natural gas. Table 2 compares hydrogen properties with other fuels and ranks their effect on safety [3] .

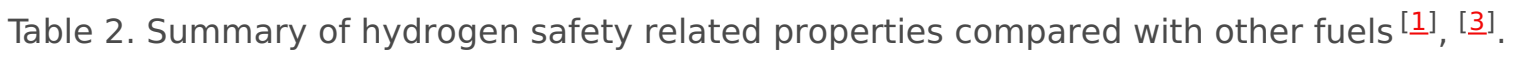




\begin{tabular}{lll}
\hline Property & Compare with other fuels & Risk \\
\hline Leak probability & Higher than other fuels & Dangerous \\
Volume of fuel released in leak & Higher than other fuels & Same as other fuels \\
Energy of fuel released in leak & Lower than other fuels & Safe \\
Diffusivity and buoyancy & Higher than other fuels & Safe \\
Lower flammability limit in air & Higher than other fuels & Same as other fuels \\
Minimum ignition energy & Lower than other fuels & Same as other fuels \\
Ignition energy at LFL & $\sim$ Same as other fuels & Same as other fuels \\
Flame velocity & Higher than other fuels & Dangerous \\
Lower detonability fuel/air ratio & Higher than other fuels & Safe \\
Explosive energy per energy stored & Lower than other fuels & Safe \\
Flame visibility & Lower than other fuels & Dangerous \\
Flame emissivity & Lower than other fuels & Safe \\
Flame fumes toxicity & Lower than other fuels & Safe \\
Fuel toxicity & Lower than other fuels & Safe \\
\hline
\end{tabular}

\section{Hydrogen as an Internal Combustion Engine Fuel}

Hydrogen is an alternative fuel resource that can be produced through the expenditure of energy as a replacement for declining reserves of conventional fossil fuels. It has long been recognized as a fuel has some unique and highly desirable properties for application in engines. These features give hydrogen excellent potential as a fuel to meet the ever more stringent environmental controls of exhaust emissions from combustion devices, including the reduction of greenhouse gas emissions []ㅡ, [느.

The use of hydrogen as an internal combustion engine fuel, as a primary or supplementary fuel, appears to promise a significant improvement in the performance of a spark ignition engine. Besides being the cleanest burning chemical fuel, hydrogen can be produced from water (using non-fossil energy) and conversely, on combustion forms water again by closed cycle. The self-ignition temperature of the hydrogen/air mixture is greater than that of the other hydrocarbon fuels and, therefore a small amount of hydrogen addition produces an antiknock quality of fuel. Hydrogen is characterized by having the highest energy-mass coefficient of the chemical fuel and in terms of mass energy consumption it exceeds the conventional gasoline fuel by about 3 times, alcohol 5 to 6 times, methane and propane 2.5 times. Therefore the results clearly establish that the supplemental hydrogen can increase the effective efficiency of the engine and reduce the specific fuel consumption. A small amount of hydrogen mixed with hydrocarbon fuel and air produces a combustible mixture, which can be burned in a conventional spark ignition engine at an equivalence ratio below the lean flammability limit of hydrocarbon fuel/air mixture. The resulting ultra-lean combustion produces low flame temperature and leads directly to lower heat transfer to the walls, higher engine efficiency and lower exhaust of CO and NOx. The burning velocity of hydrogen/air mixture is about seven times higher than that of all hydrocarbon-fuel/air mixture. As the burning velocity rises, the actual indicator diagram approaches closer to the ideal diagram and a higher thermodynamic efficiency is achieved. The high molecular diffusivity of the hydrogen into the air improves the mixture uniformity and hence the combustion efficiency and cycle-tocycle variation. The using of gaseous fuel (rather than a liquid fuel) for short periods during cold start and warm-up, avoids problems of cold fuel evaporation, uneven distribution of the fuel to the different cylinders due to the presence of a liquid film on the walls of the intake manifold and to unwanted large variations in supplied air-fuel ratio during transient conditions such as acceleration and deceleration. Table 3 shows the properties of hydrogen and the hydrocarbon fuels [3] . 
Table 3. Comparison properties of hydrogen and hydrocarbon fuels.

\begin{tabular}{|c|c|c|c|c|c|c|}
\hline Property & Hydrogen & Methane & Propane & Ethanol & Methanol & Gasoline \\
\hline Chemical Formula & $\mathrm{H}_{2}$ & $\mathrm{CH}_{4}$ & $\mathrm{C}_{3} \mathrm{H}_{8}$ & $\mathrm{C}_{2} \mathrm{H}_{5} \mathrm{OH}$ & $\mathrm{CH}_{3} \mathrm{OH}$ & $\mathrm{C}_{8} \mathrm{H}_{18}$ \\
\hline Molecular Weight & 2.02 & 16.04 & 44.1 & 46.07 & 32.04 & 102 \\
\hline Molar carbon to hydrogen ratio & 0.000 & 0.250 & 0.375 & 0.333 & 0.250 & 0.444 \\
\hline Stoichiometric air/fuel ratio, mass & 34.32 & 17.20 & 15.67 & 9.00 & 6.45 & 15.11 \\
\hline Latent heat of vaporization $(\mathrm{kJ} / \mathrm{kg})$ & 446 & 509 & 449 & 921 & 1176 & 348 \\
\hline Lower heating value (MJ/kg) & 119.93 & 50.02 & 46.40 & 26.86 & 19.93 & 44.50 \\
\hline Flammability limits ( $\%$ by volume) & $4.1-74$ & $5.3-15$ & $2.2-9.5$ & $4.3-19$ & $7.3-36$ & $1.4-6.7$ \\
\hline Self-ignition temperature $\left({ }^{\circ} \mathrm{K}\right)$ & 855 & 813 & 755 & 696 & 737 & 530 \\
\hline Combustion speed in air $(\mathrm{m} / \mathrm{s})$ & 2.933 & 0.355 & 0.432 & 0.455 & 0.455 & 0.356 \\
\hline Octane number $(\mathrm{R}+\mathrm{M}) / 2$ & $130+(\mathrm{R})$ & $120+$ & 104 & 100 & 100 & $86-94$ \\
\hline
\end{tabular}

Flexible-fuel engines are designed to use several fuels. Flexible-fuel engines are able to use a variable mixture of two or more different fuels, as long as they are alike physically [4]. Vehicles with flexible-fuel engines are not in widespread use since dedicated-fuel vehicles that operate on a single fuel are typically cheaper. Most gasoline-powered engines can be converted to dual-fuel engines with natural gas/propane or hydrogen for example []. The conversion does not require the removal of any of the original equipment. A natural gas/propane or hydrogen pressure tank is added, along with a fuel line to the engine through special mixing equipment $[\underline{6}]$. A switch selects either gasoline, of gas fuel like hydrogen or natural gas/propane operation [4]. Diesel vehicles can also be converted to a dual-fuel configuration [].

Hydrogen is found as a suitable alternative fuel for spark ignition engines with certain drawbacks such as high NOx emission and small power output. However, supercharging may solve such problems. The effect of equivalence ratio, compression ratio and inlet pressure on the performance and NOx emission of a four stroke supercharged hydrogen engine has been studied experimentally and analyzed using a specially developed computer program []ㅛ. A chart specifying the safe operation zone of the hydrogen

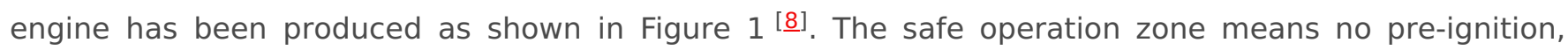
acceptable NOx emission, high engine efficiency and lower s.f.c. in comparison with the gasoline engine. The study also shows that supercharging is a more effective method to increase the output of hydrogen engine rather than increasing the compression ratio of the engine at the knock-limited equivalence ratio. 


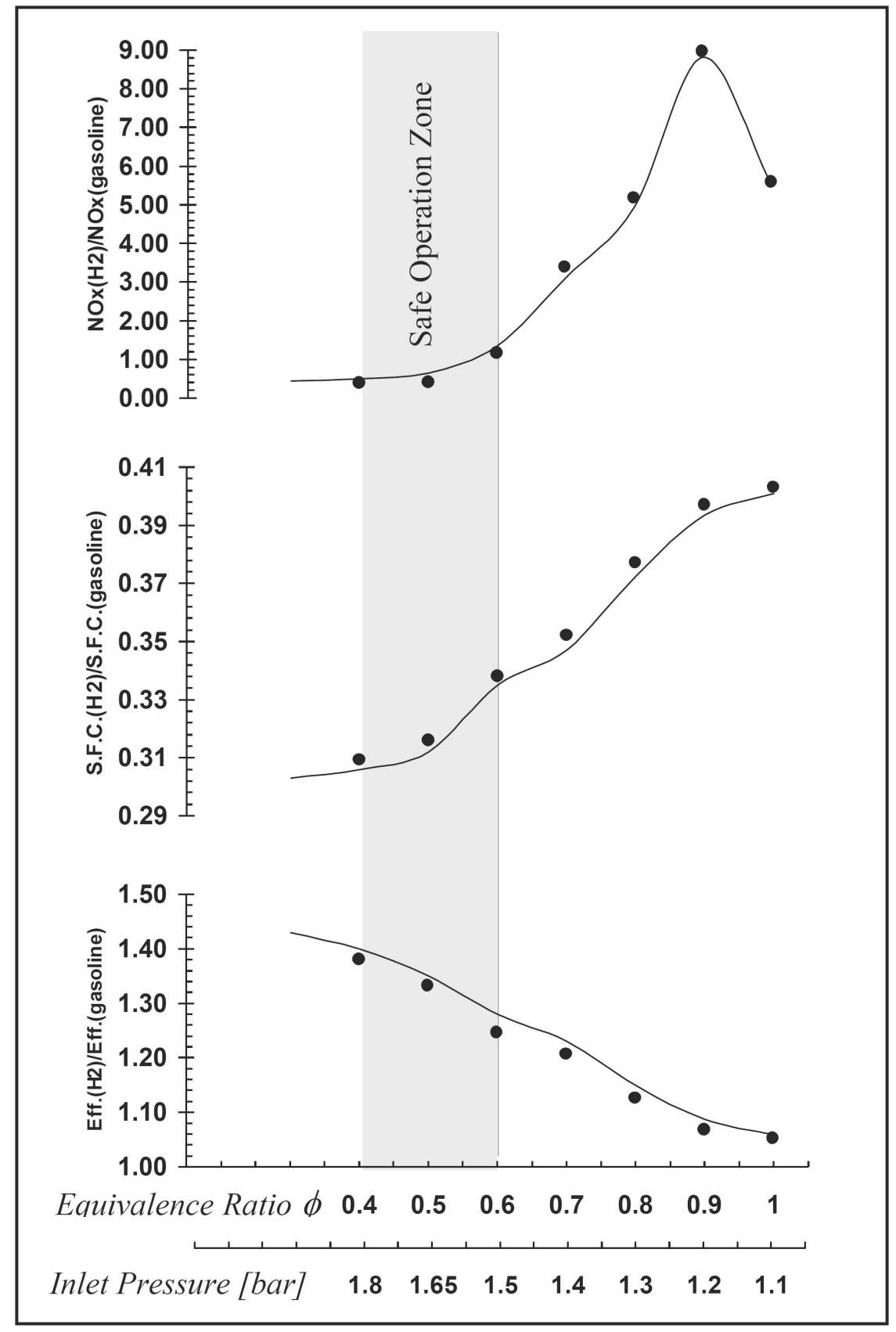

Figure 1. Measurements (dots) and predictions (solid lines) of engine performance and emission [ㄹ]

Researchers have found that hydrogen presents the best and unprecedented solution to the energy crises and pollution problems, for its superior combustion qualities and availability.

A comprehended study to provide data on the effect of compression ratio, equivalence ratio and engine speed on the engine performance and emissions of a spark ignition engine operating on hydrogen fuel has been conducted [9]. An analytical model was developed, tested and verified against the experimental data of the engine. The model is used to study and to provide data on the effect of compression ratio, equivalence ratio and engine speed on engine power, optimum spark timing, thermal efficiency, specific fuel consumption, exhaust gas temperature and NOx emission of a carbureted engine operating on hydrogen fuel. This data is very important in order to get to a better understanding of the interaction between engine performance and emission parameters, which will help engine designers while designing for hydrogen. Figure 2 shows one sample from this data [9]. 


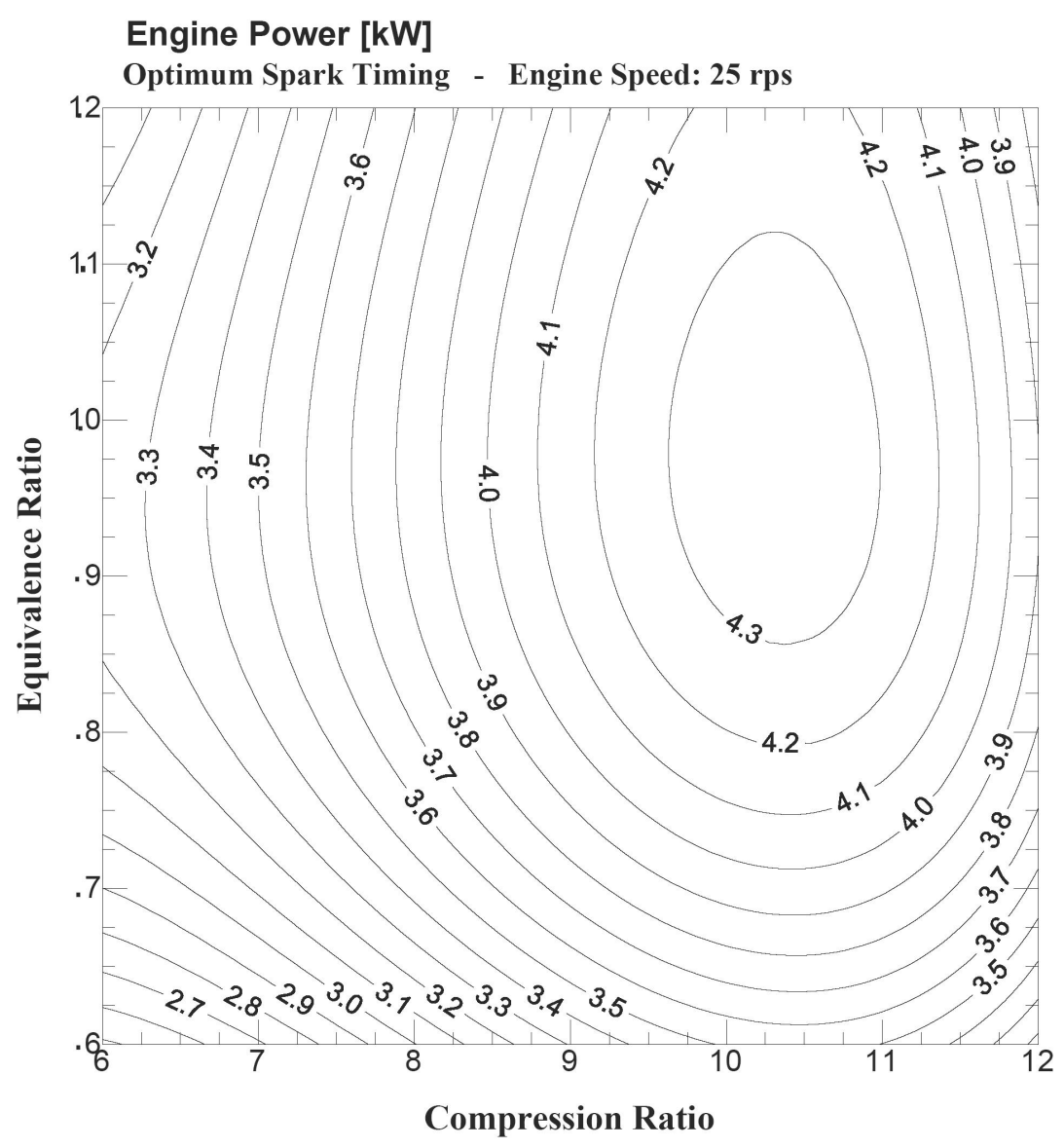

Figure 2. Effect of compression ratio and equivalence ratio on the hydrogen engine power $[\underline{9}]$.

In hydrogen-fuelled spark ignition engine applications, the onset of pre-ignition remains one of the prime limitations that need to be addressed so as to avoid its incidence and achieve superior performance [1ㅇ]. Hydrogen requires a very low ignition energy, which leads to uncontrolled pre-ignition problems. Preignition in hydrogen-fueled spark ignition engines is an acknowledged barrier to the further improvement of efficiency and increased power. Pre-ignition is caused mainly by the auto-ignition of the fresh gas mixture of the charge before the spark ignition time during the compression stroke. It will lead to the incidence the peak cylinder pressure before top dead center, undesirable combustion, involves exceedingly rapid rates of combustion of the fuel-air mixture, increased heat transfer to the cylinder walls, high cylinder pressure and temperature levels and increased emissions $[\underline{11}$. These lead to highly undesirable engine performance and the potential damage to engine components when allowed to persist $[\underline{10]},[11]$.

The effects of changes in key operating variables, such as compression ratio, spark timing, intake pressure and temperature on pre-ignition limiting equivalence ratios have been established both analytically as well as experimentally [10]. With the established pre-ignition model, it is possible not only to investigate whether pre-ignition is observed with changing operating and design parameters, but also to evaluate their effects on the maximum possible pre-ignition intensity. The results show the possibility of retarding or advancing in spark timing from the minimum advance for best torque (MBT) within the pre-ignition and abnormal combustion limits (Figure 3). "Abnormal Combustion" is caused by the occurrence of the peak cylinder pressure before top dead center, and this may lead to highly undesirable engine performance and potential damage to engine components when allowed to persist. As can be seen from the figure, the variation in spark timing is very effective in controlling the combustion process. It was found that the operational region tends to narrow with increasing the equivalence ratio reaching to 2.5 degree crank angle for retarding and 3 degree crank angle for advancing at 0.935 equivalence ratio. The tendency to pre-ignition depended on the cylinder pressure and fresh gas temperature during the compression stroke. The increases of the strength of the fuel mixture causes increases in the thermal energy liberated from the mixture, which increases the flame temperature, 
hence increasing the fresh gas temperature during the compression stroke, and therefore, the tendency to pre-ignition increases. Accordingly, it is critically important not only to avoid pre-ignition or abnormal combustion, but also to know the limiting conditions for its incidence under any set of operating and designing conditions.

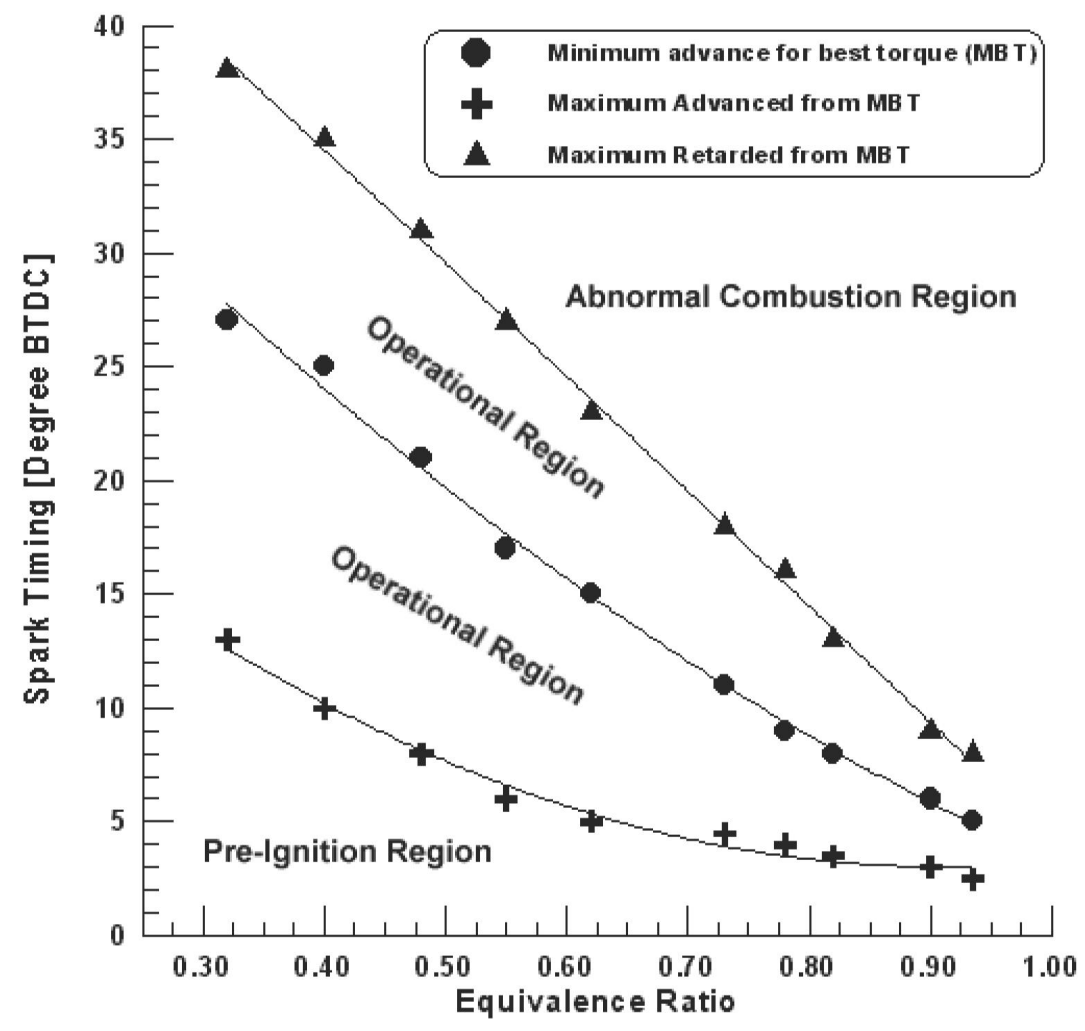

Figure 3. Measured (symbols) and predicted (solid line) variation in the pre-ignition, abnormal combustion and operational regions with change in spark timing (compression ratio $=11$, engine speed $=25 \mathrm{rev} / \mathrm{s}, \mathrm{Tin}=313 \mathrm{~K}, \operatorname{Pin}=1 \mathrm{bar})[10]$.

A number of challenges that accompanying with hydrogen spark ignition engines such as less power, pre-ignition, and knock have been investigated and studied in detail to modify hydrogen spark ignition engines successfully [12], [13], [14]. Review is made of the positive features and the critical limitations associated with the use of hydrogen as a spark ignition engine fuel [12]. The performance and pollutant emissions of a Ricardo E6/Us spark ignition engine fueled with hydrogen have been studied in detail. The hydrogen results were compared to results of gasoline fuel at the same engine and at the same operation conditions as shown in Figure 4 [를. 


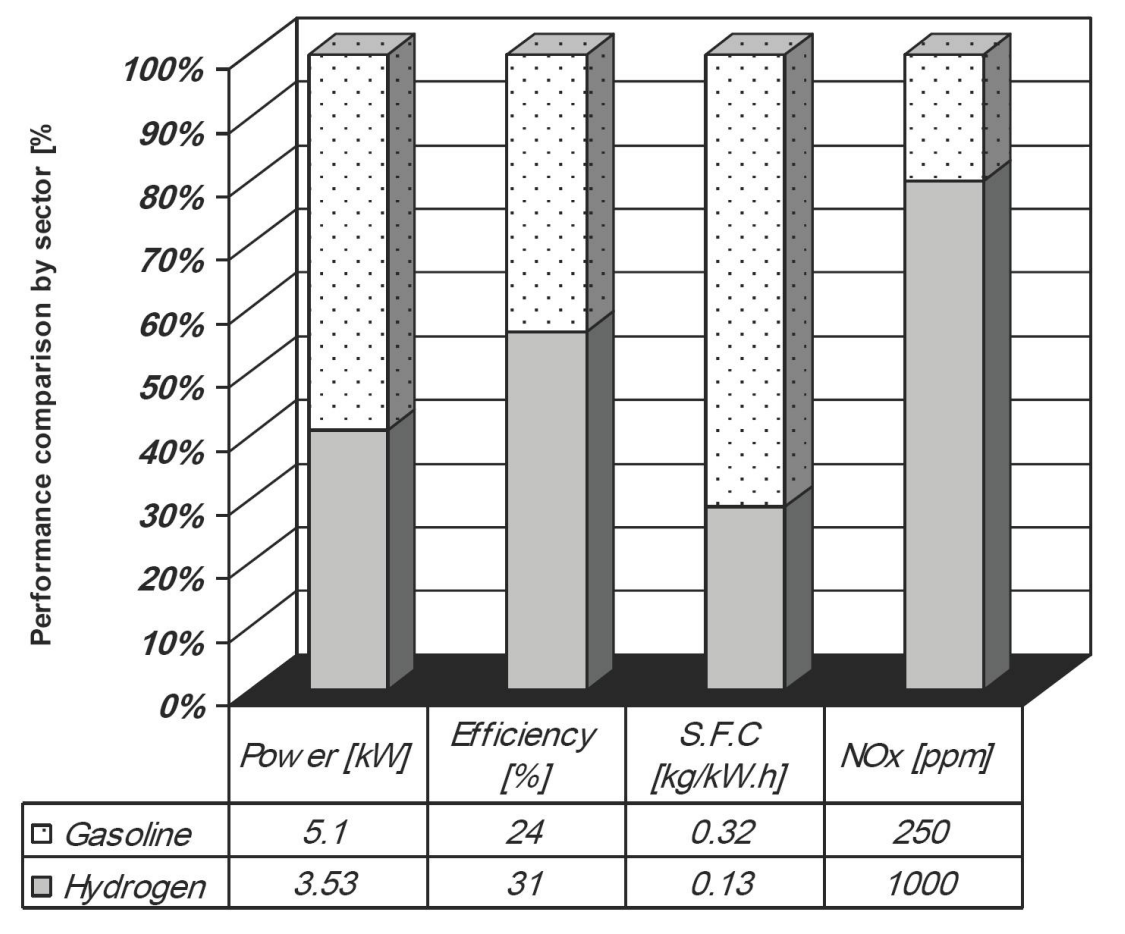

Figure 4. Comparison of performance and pollutants of a hydrogen and a gasoline spark ignition engine operating at a compression ratio (7: 1), an equivalent ratio (1.0) and optimum spark timing [12].

Computer simulations of internal combustion engine cycles are desirable because of the aid they provide in design studies, in predicting trends, in serving as diagnostic tools, in giving more data than are normally obtainable from experiments, and in helping to understand the complex processes that occur in the combustion chamber. Knowledge of gas composition and properties is required for thermodynamic cycle calculations, which play an increasing part in the design and development of all types of internal combustion engines ${ }^{[15]}$. For a given air to fuel ratio and total pressure, the equilibrium composition is a function of temperature only, while the kinetic composition is also a function of the rate of change of temperature and the previous history of a gas. Figure 5 shows the one sample of the results of the equilibrium composition -twelve species- obtained at 30 bar pressure, stoichiometric mixture, for hydrogen fuel [1ㄷ]. 


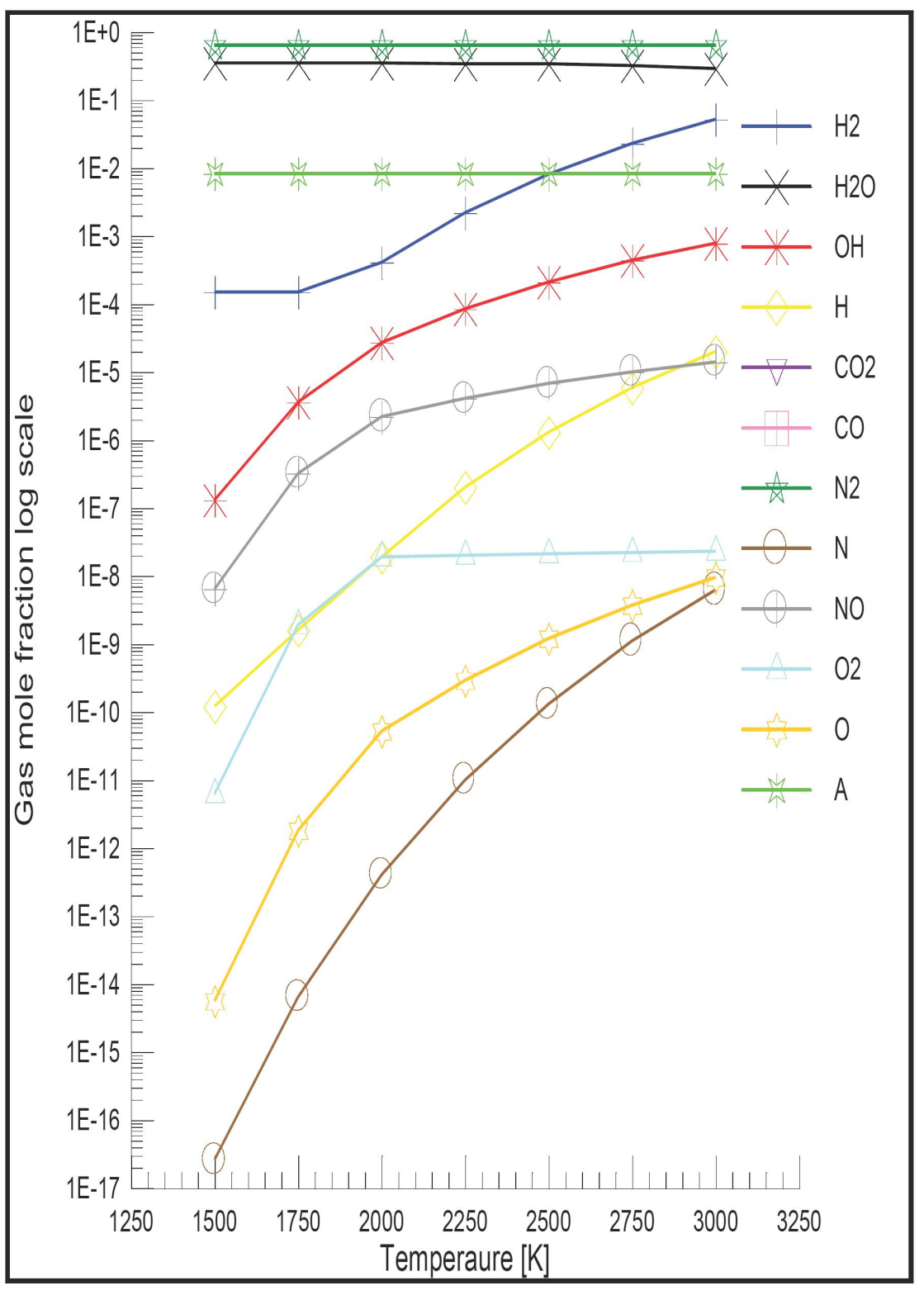

Figure 5: Mole fraction of combustion products of the hydrogen fuel at 30 bar pressure and stoichiometric mixture [15] .

The use of hydrogen as a supplementary fuel in automotive appears to promise a significant improvement in the performance of a spark ignition engine [16]. The supplemental hydrogen can increase the effective efficiency of the engine and reduce the specific fuel consumption. A small amount of hydrogen mixed with gasoline and air produces a combustible mixture, which can be burned in a conventional spark ignition engine at an equivalence ratio below the lean flammability limit of gasoline/air mixture. The resulting ultra-lean combustion produces low flame temperature and leads directly to lower heat transfer to the walls, higher engine efficiency and lower exhaust of CO and NOx. The high molecular diffusivity of the hydrogen into the air improves the mixture uniformity and hence the combustion efficiency and cycle-to-cycle variation. The using of gaseous fuel (rather than a liquid fuel) for short periods during cold start and warm-up, avoids problems of cold fuel evaporation, uneven distribution of the fuel to the different cylinders due to the presence of a liquid film on the walls of the intake manifold and to unwanted large variations in supplied air-fuel ratio during transient conditions such as acceleration and deceleration.

The effect of hydrogen blending with gasoline on fuel consumption and pollutant concentrations of a spark ignition engine has been studied $[\underline{16}$. The results show that the maximum improvement in engine thermal efficiency occurs at $8 \%$ hydrogen blending (Figure 6). The results also show that $10 \%$ hydrogen blending reduces $\mathrm{CO}$ concentration by $73.8 \%$ but the NO concentration increases by $100 \%$. However the problem of increasing NO concentration was solved by operating the engine with lean mixture. 
Hydrogen blending also reduces the specific fuel consumption until about $6 \%$ blending, then the effect becomes marginal.
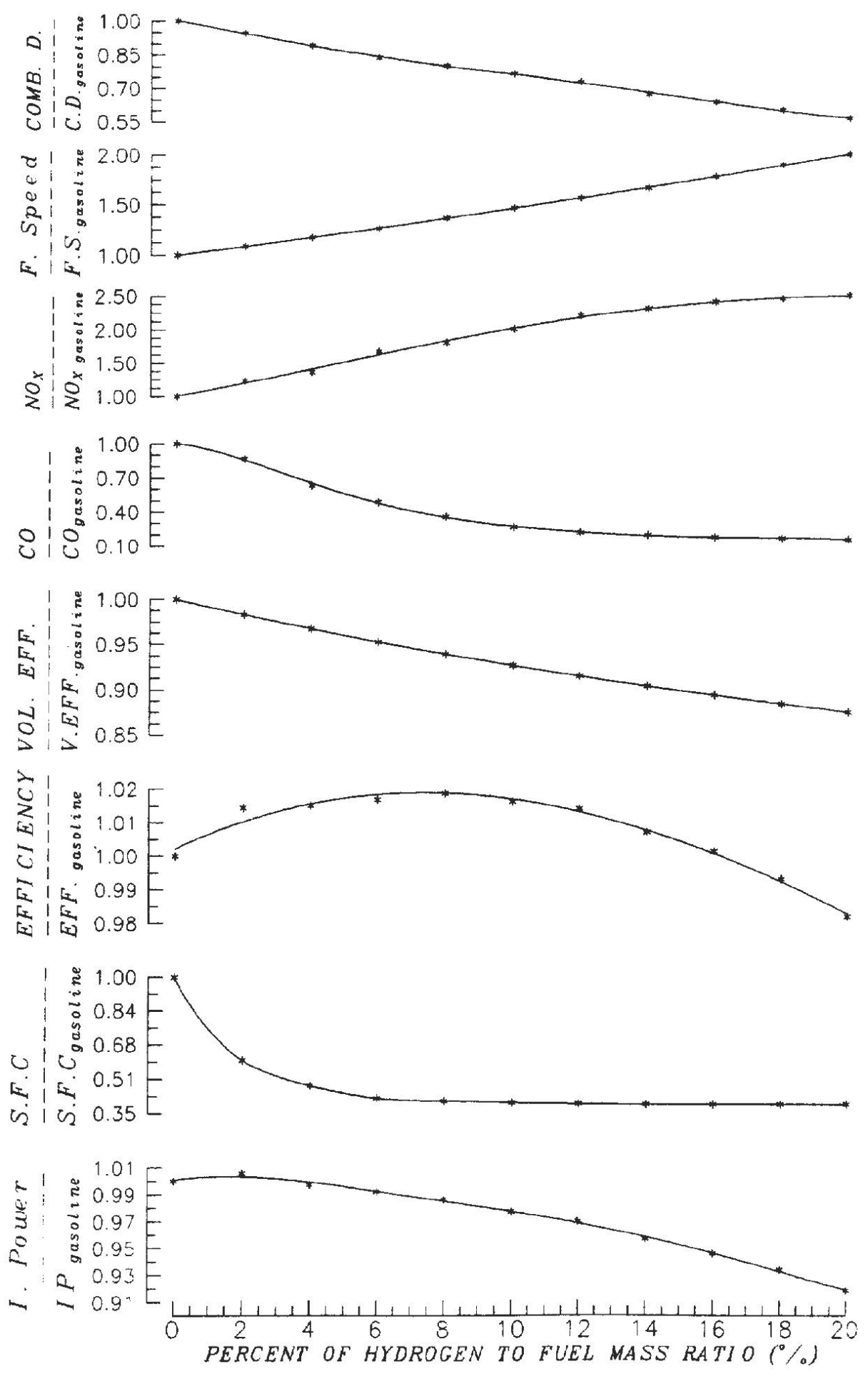

Figure 6: Effect of hydrogen blending as supplemented fuel to gasoline on the performance and emission of a Ricardo E6/Us SI engine. Equivalence ratio: 1, compression ratio: 7.5, engine speed: 1500 rpm, optimum spark advance $[\underline{16]}$.

Ethanol, or grain alcohol, is an alcohol fuel that has been more widely used as automotive fuel ${ }^{[\underline{17}]}$. It can be made from a variety of feedstocks, mainly grains, forest resides, and solid waste. It can be used in its pure form, but is more widely used in a blended form. Gasoline blends using $85 \%$ gasoline and $15 \%$ ethanol have been widely available in many areas of the country (E85). ETBE is a feedstock for reformulated gasoline based on ethanol. The using of alcohol as blended fuels in internal combustion engines will reduces the temperature of the intake manifold due to it has a high latent heat of vaporization [르. The addition of ethanol alcohol from 0 to $30 \%$ by volume to gasoline fuel will increases engine power, thermal efficiency and specific fuel consumption, and reduces NOx, CO, and HC emissions 
[18]. The ethanol added improves the combustion process, reduces the crevices flow energy, reduces the cylinder temperature, reduces the ignition delay, speed up the flame front propagation, reduces the combustion duration and retards the spark timing. The high useful compression ratio, which produced maximum engine power, was directly proportional with ethanol percentage in mixture [1ㅁ] .

A hydrogen-gasoline fueled engine generally develops lower maximum power and higher NOx emissions compared to an equivalent gasoline engine, due to the restricted air flow and increase of the maximum temperature inside the cylinder, respectively. To decrease the amount of NOx emissions, hydrogen is added at lean combustion operation. These conditions (lean mixture blended with hydrogen) give lower levels of NOx emissions compared with that of a pure gasoline operation, but with more deterioration in engine power.

The ethyl alcohol has been added with different volume ratios to the gasoline fuel to improve the output power and reduction the NOx emission of hydrogen-supplemented fuel engine [20]. The results of the study showd that all engine performance parameters have been improved when operating the gasoline SI engine with dual addition of hydrogen and ethyl alcohol. It has been found that $4 \%$ of hydrogen and $30 \%$ of ethyl alcohol blending causes a $49 \%$ reduction in CO emission, a $39 \%$ reduction in NOx emission, a $49 \%$ reduction in specific fuel consumption and increases in the thermal efficiency and output power by 5 and $4 \%$, respectively [20]. The advantage of the hydrogen-supplemented fuel is that it requires a smaller quantity of hydrogen, which considerably reduces the problems connected with hydrogen storage in the automobile [21],$[22]$. 


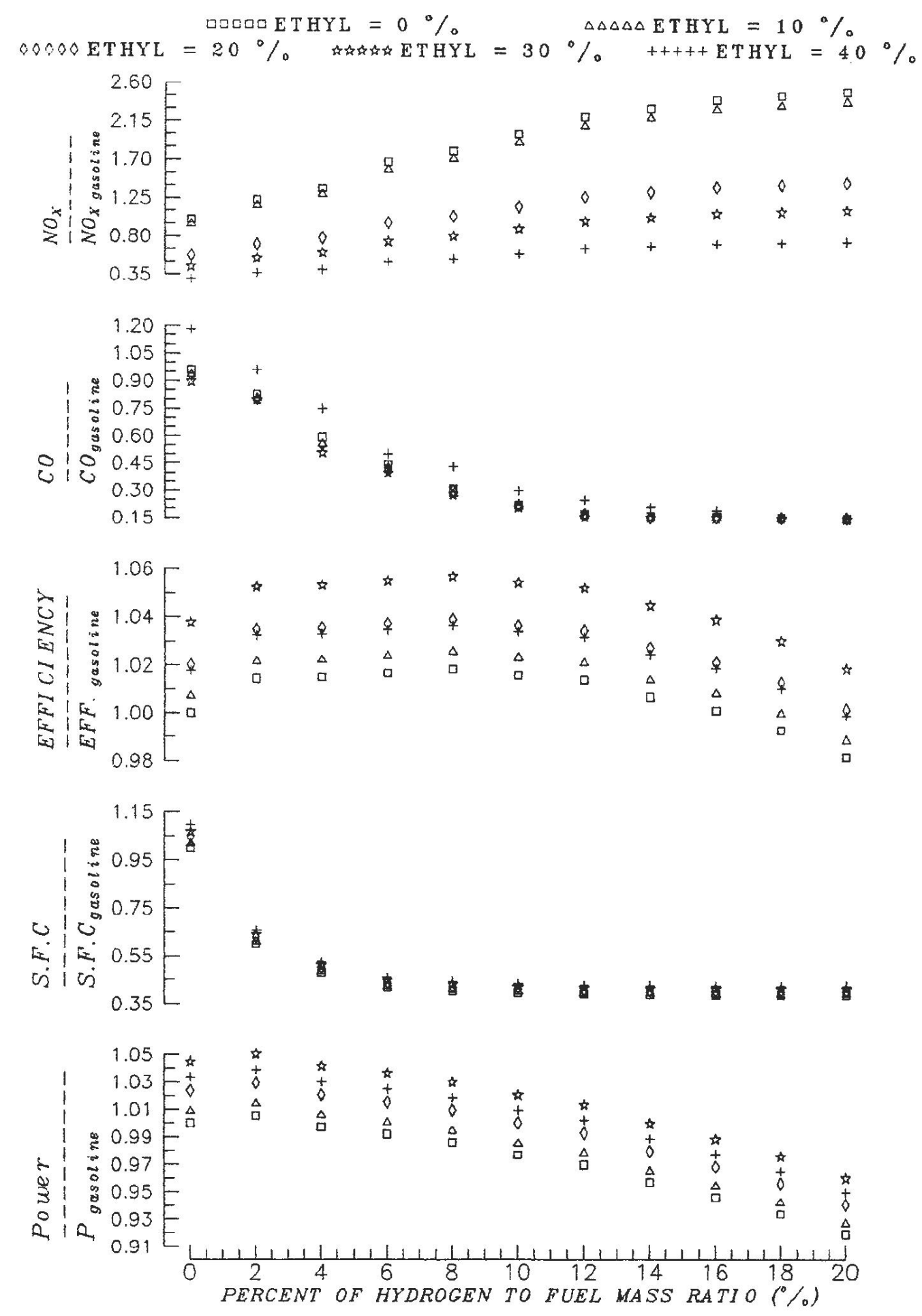

Figure 7. Measurements of the effect of hydrogen/alcohol blending as supplemented fuels to gasoline on the performance and emission of SI gasoline engine [20].

The important improvements of alcohol addition are to reduce the NOx emission with increasing the higher useful compression ratio and output power of hydrogen-supplemented engine. An equation has been derived from experimental data to specify the least quantity of ethyl alcohol blended with gasoline and satisfying constant NOx emission when hydrogen added [르. A chart limiting the safe operation zone of the engine fueled with dual renewable supplemented fuel, (hydrogen \& ethyl alcohol) has been produced (Figure 8). The safe zone provides lower NOx and CO emission, lower specific fuel consumption and higher brake power compared to an equivalent gasoline engine [르]. 


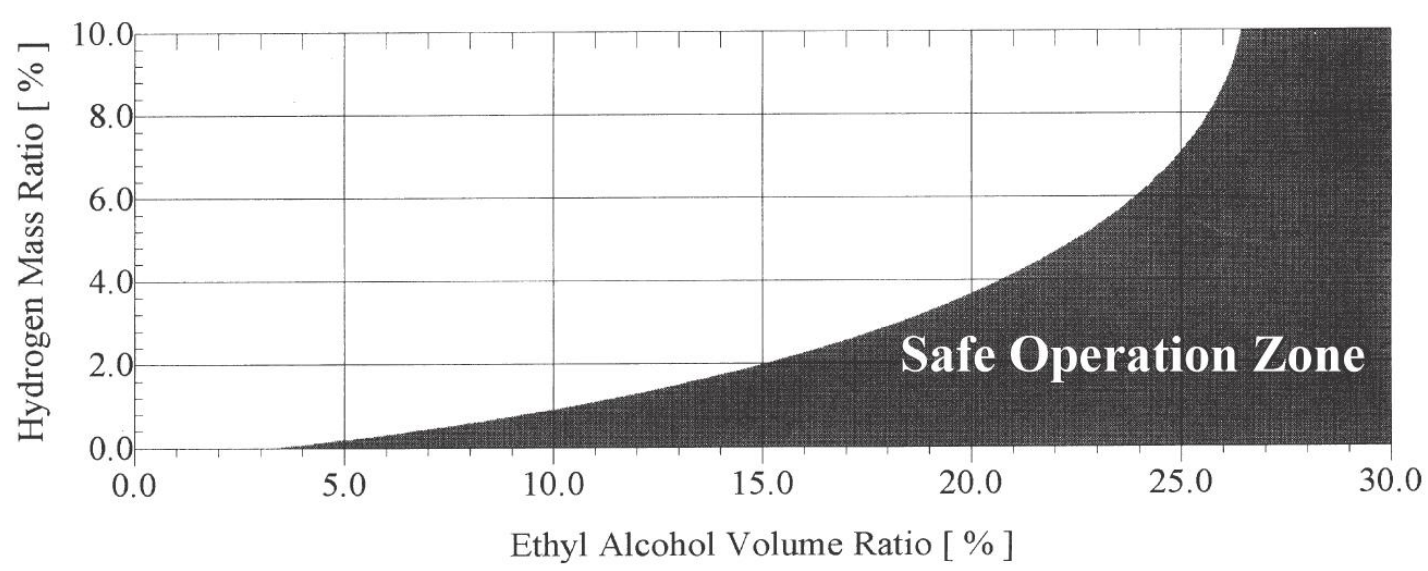

Figure 8. The safe operation zone of the engine fueled with hydrogen and ethyl alcohol as supplemented fuels to gasoline $[\underline{23]}$.

The performance and pollutant emission of a four-stroke spark ignition engine using hydrogen-ethanol blends as fuel has been studied [2ㄴ]. The results show that the supplemental hydrogen in the ethanol-air mixture improve the combustion process and hence improve the combustion efficiency, expand the range of combustibility of the ethanol fuel, increase the power, reduce the specific fuel consumption, and reduce toxic emissions. Ethanol fuel has high heat of vaporization, therefore, it reduces the peak temperature inside the cylinder and hence reduces the NOx emissions. Nitrogen oxide emissions increased as the percentage of hydrogen addition increases. The increasing of CR caused an increase in NOx emission, however, ethanol fuel at $12 \mathrm{CR}$ and hydrogen addition (from 0 to 3.5 mass\%) was still lower than with gasoline fuel at $7 \mathrm{CR}$. In all percentages of hydrogen in ethanol the engine power was greater than with pure gasoline fuel. The important improvement of hydrogen addition is to reduce the specific fuel consumption of ethanol engines. Results were compared to those with gasoline fuel at 7 compression ratio and stoichiometric equivalence ratio (Figure 9).

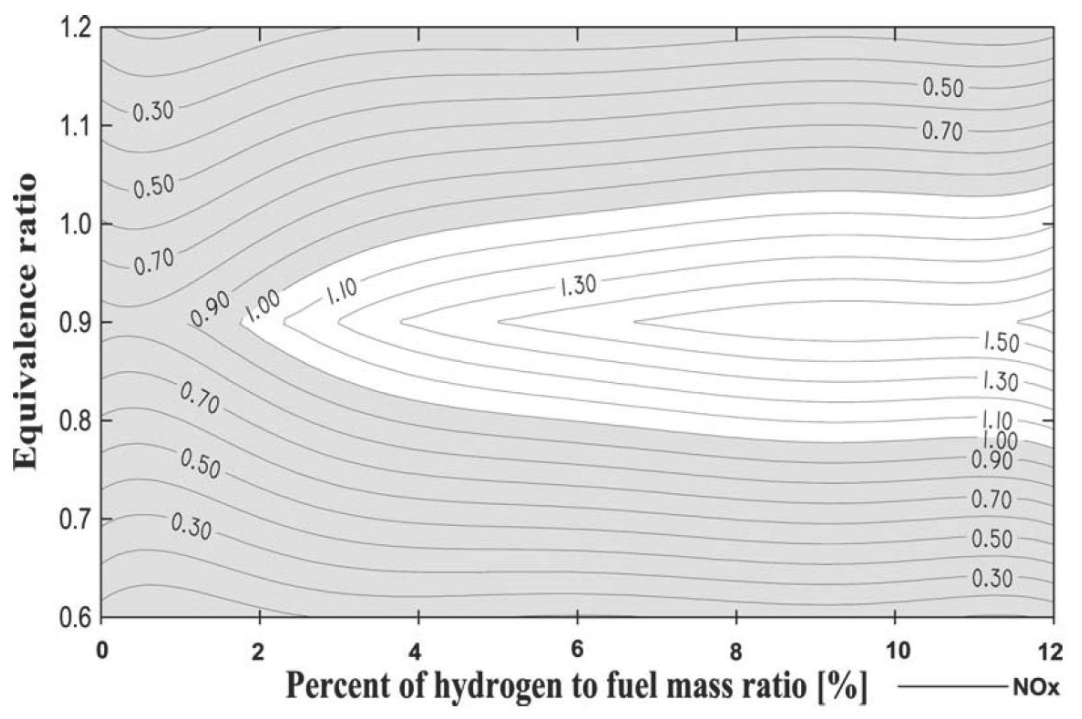

Figure 9. Effect of hydrogen blending as supplemented fuel to alcohol on the NOx emission [24] .

Methanol, also known as wood alcohol, is a colorless and odorless liquid alcohol fuel that can be made from biomass, natural gas, or coal. It is the simplest alcohol chemically, and it can be used as an automobile fuel in its pure form (M100); as a gasoline blend, typically $85 \%$ methanol to $15 \%$ unleaded gasoline (M85); or as a feedstock for reformulated gasoline. M100 may be used as a substitute for diesel. In M85, the gasoline is added to color the flame of burning fuel for safety reasons and to improve starting in cold weather.

The blending of hydrogen and methanol has been used as an alternative renewable fuel in a carbureted 
spark ignition engine [25]. The results showed that NOx concentration with methanol fueled engine were about 40 percent lower than the corresponding with gasoline (Figure 10). This is probably a result of the higher heat of vaporization of methanol, which reduces the peak temperature inside the cylinder.

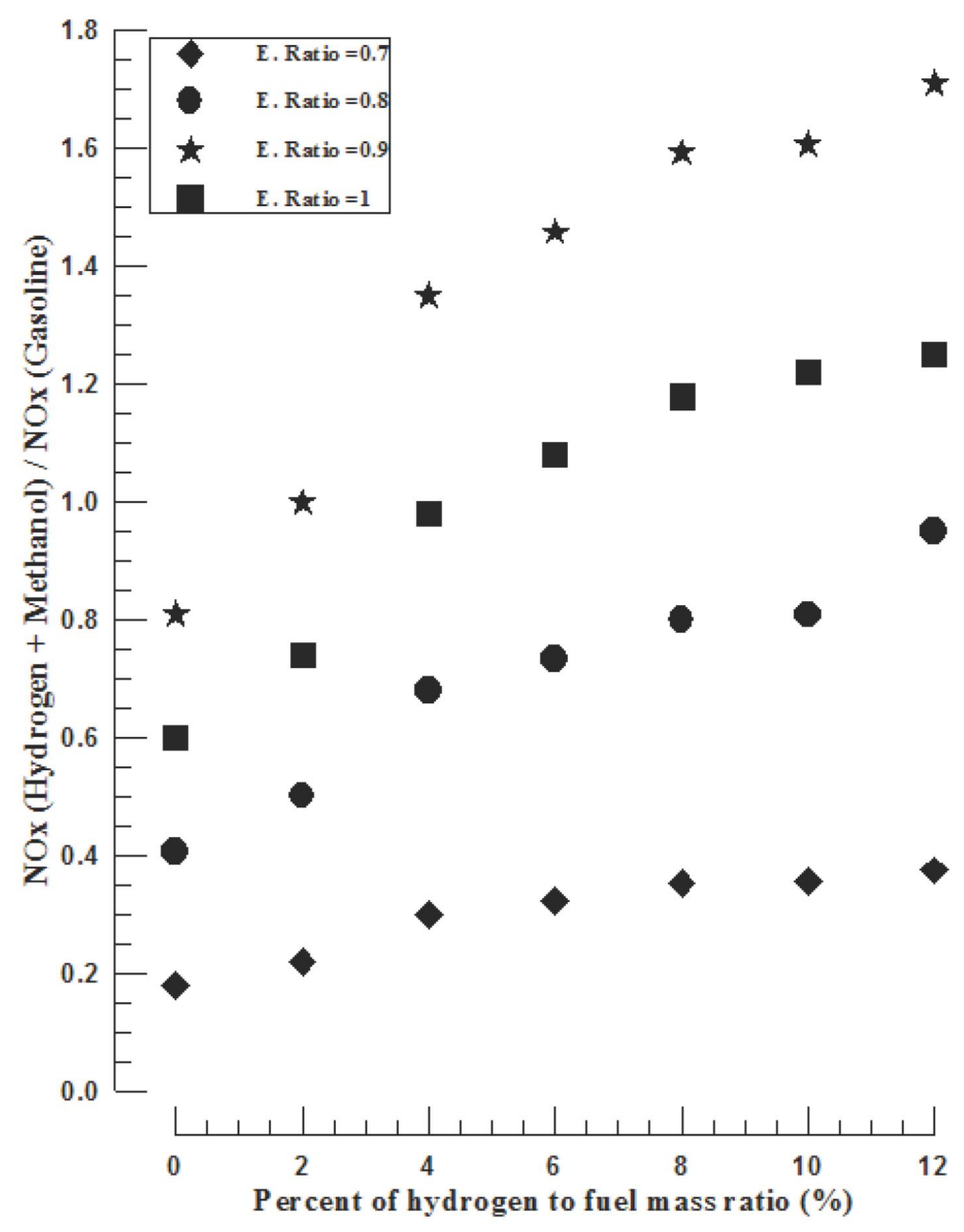

Figure 10. Effect of hydrogen addition and equivalence ratio on the NOx Emission of hydrogen-methanol spark ignition engine [2ㄷ].

Natural gas is a fossil fuel found in underground reservoirs. It consists chiefly of methane, with smaller amounts of other hydrocarbons such as ethane, propane, and butane, along with inert gases such as carbon dioxide, nitrogen, and helium. The actual composition varies, depending on the region of the source. As technology advances, unconventional natural gas deposits are beginning to make up a significant part of the supply. Before 1978, natural gas that had been discovered deep underground was left untouched. The passage of market-based regulation and the Natural Gas Policy Act provide incentives to extract these deep deposits and to spur investment in deep exploration and development. Deep gas is usually 15,000 feet underground, compared to conventional deposits which are only a few thousand feet deep. Tight gas is gas that is trapped in hard rock or limestone (tight sand). Black shale is another source where the estimated reserves have tripled in the last few years. Coalbed methane is another source that in the past was neglected and considered a problem in coal mining. It is estimated to be about $8 \%$ of total reserves.

The usage of mixture of $40 \%$ hydrogen and $60 \%$ methane by volume, as supplementary fuel to alcoholair mixture for spark ignition engines results in considerable improvement of the engine performance and in the reduction of the toxic components in the exhaust gases in comparison with the conventional spark ignition gasoline engine [르]. The performance of the engine is enhanced when relatively small amounts of hydrogen are present with methane. This improvement in performance, which is especially pronounced at operational equivalence ratios that are much leaner than the stoichiometric value, can be attributed largely to the faster and cleaner burning characteristics of hydrogen in comparison to 
methane or alcohol. The increasing of compression ratio caused a reduction in the allowable gaseous fuel addition to achieve an acceptable level of NOx emissions (Figure 11).

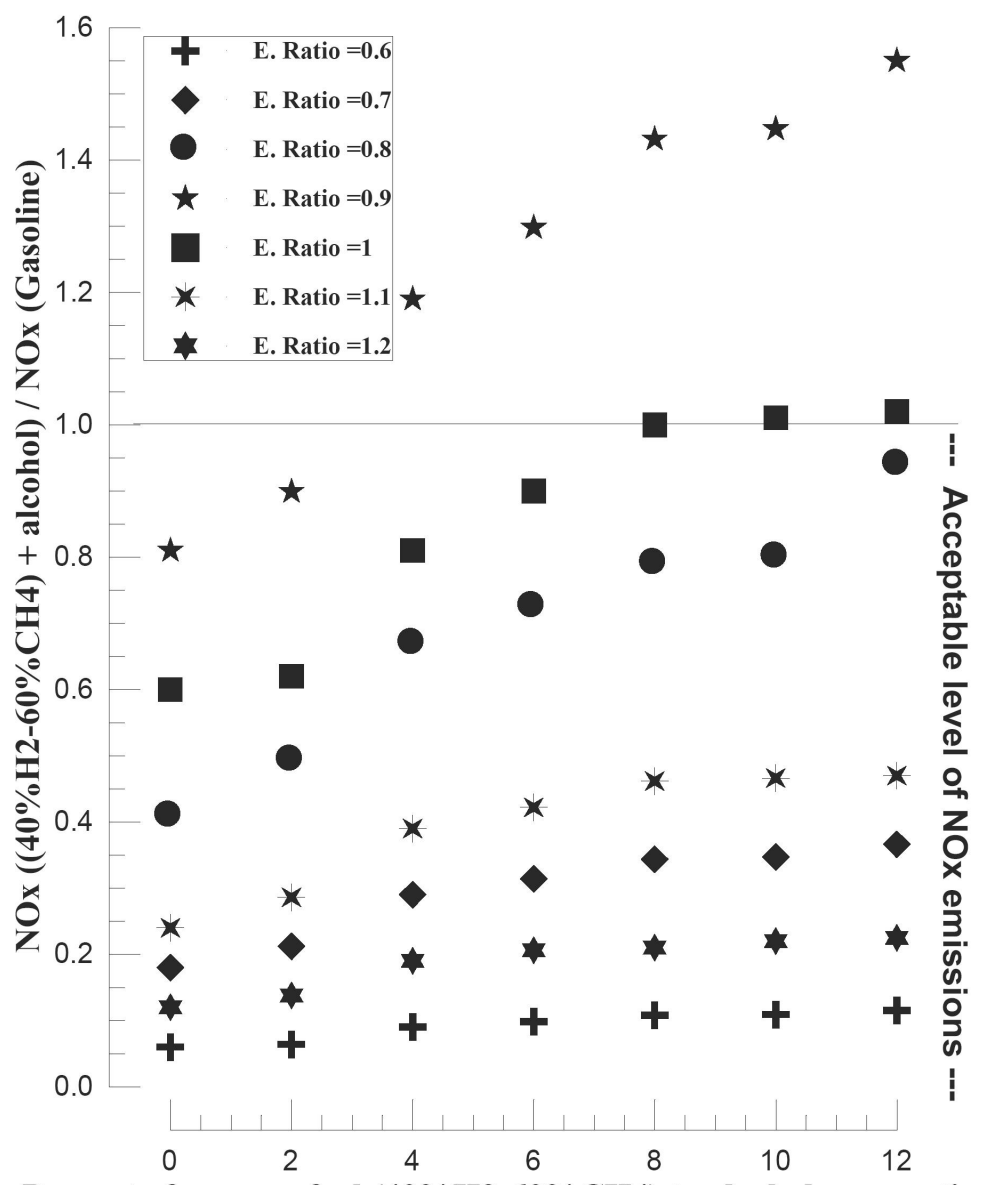

Percent of gaseous fuel $(40 \% \mathrm{H} 2-60 \% \mathrm{CH} 4)$ to alcohol mass ratio

Figure 11. Effect of gaseous fuel $\left(40 \% \mathrm{H}_{2}-60 \% \mathrm{CH}_{4}\right)$ addition and equivalence ratio on the NOx emission $[\underline{26}]$.

Hydrogen addition to methane fuel was found to be a possible mixture for operation of a $\mathrm{Cl}$ engine in $\mathrm{HCCl}$ mode. The heat release rate of hydrogen fuel is extremely high, which leads to high ignition timing control requirements [27]. Controlling the ignition timing in accordance with the operating conditions is crucial for utilizing $\mathrm{HCCl}$ combustion engines. The results showed that the hydrogen is an effective ignition controller for $\mathrm{HCCl}$ combustion of methane [27]. The effective ignition control by hydrogen can expand the operation range of equivalence ratios and engine loads in $\mathrm{HCCl}$ combustion [2].

\section{Hydrogen and Fuel Cells}

Fuel Cell system is an advanced power system for the future that is sustainable, clean and environmental friendly. Fuel Cells are electrochemical devices that directly convert the chemical energy of hydrogen fuel into electricity. In general, fuel cells offer many advantages over conventional energy conversion devices. Fuel cells have higher energy efficiencies, silent, vibration free and zero emissions at point of use. One major advantage of hydrogen fuel cells becomes apparent when we compare their efficiencies to the efficiency of a hydrogen internal combustion engine. The efficiency range for the hydrogen fuel cells rang from 45 to $75 \%$. Whereas, the typical efficiency of an internal combustion engine fueled with hydrogen is on the order of $35 \%\left[{ }^{[29]}\right.$. The hydrogen fuel-cells convert compressed hydrogen from their fuel tanks into electricity that powers the electric motor in the vehicle, providing a similar range to vehicles powered by internal combustion engines using hydrogen or fossil fuels.

The effect of operation conditions on the cell performance has been investigated ${ }^{[30]}$. The results ware 
indicated that the operating temperature and pressure can be optimized, based on cell performance, for given design and other operating conditions. For most applications, and particularly for steady operation, a fuel cell does not have to be operated at its maximum power, where the efficiency is the lowest. When higher nominal cell potential is selected, savings on fuel cost offset the cost of additional cells (Figure 12). Also the study provided a model of electrochemical reactions and current distribution inside the fuel cell to be used as a computer-aided tool for design and optimization of future fuel cell engines with much higher power density and lower cost [30].

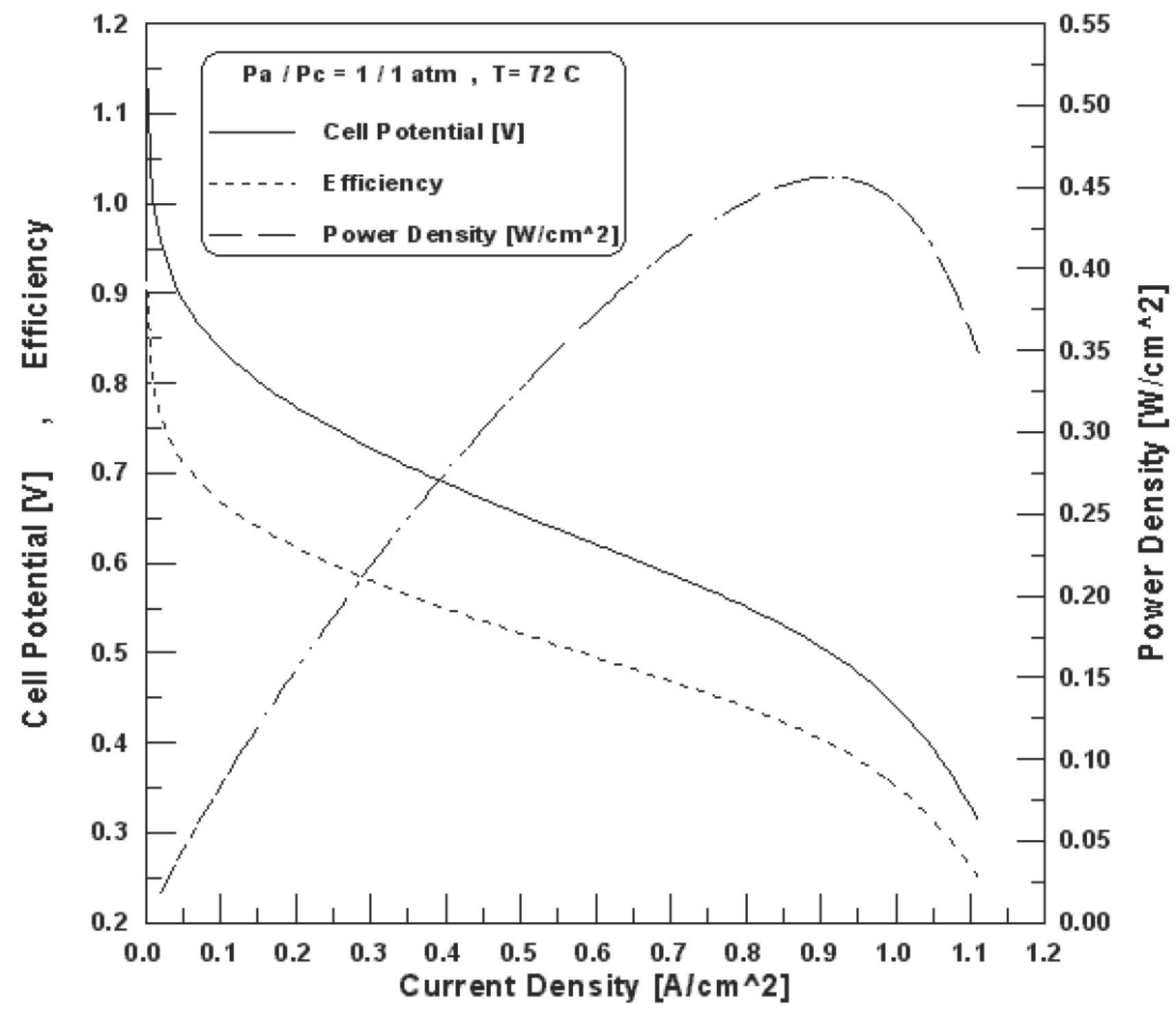

Figure 12. Fuel cell polarization curve, efficiency and power density [르].

The fuel cell efficiency is directly proportional to the cell potential, therefore, the efficiency is also a function of power density. Figure 13 shows the cell potential-power density relationship for the hydrogen fuel cell polarization curve [31]. The efficiency at maximum power is much lower than the efficiency at partial loads, which makes the fuel cells very attractive and efficient for applications with highly variable loads where most of the time the fuel cell is operated at low load and high efficiency [32]. 


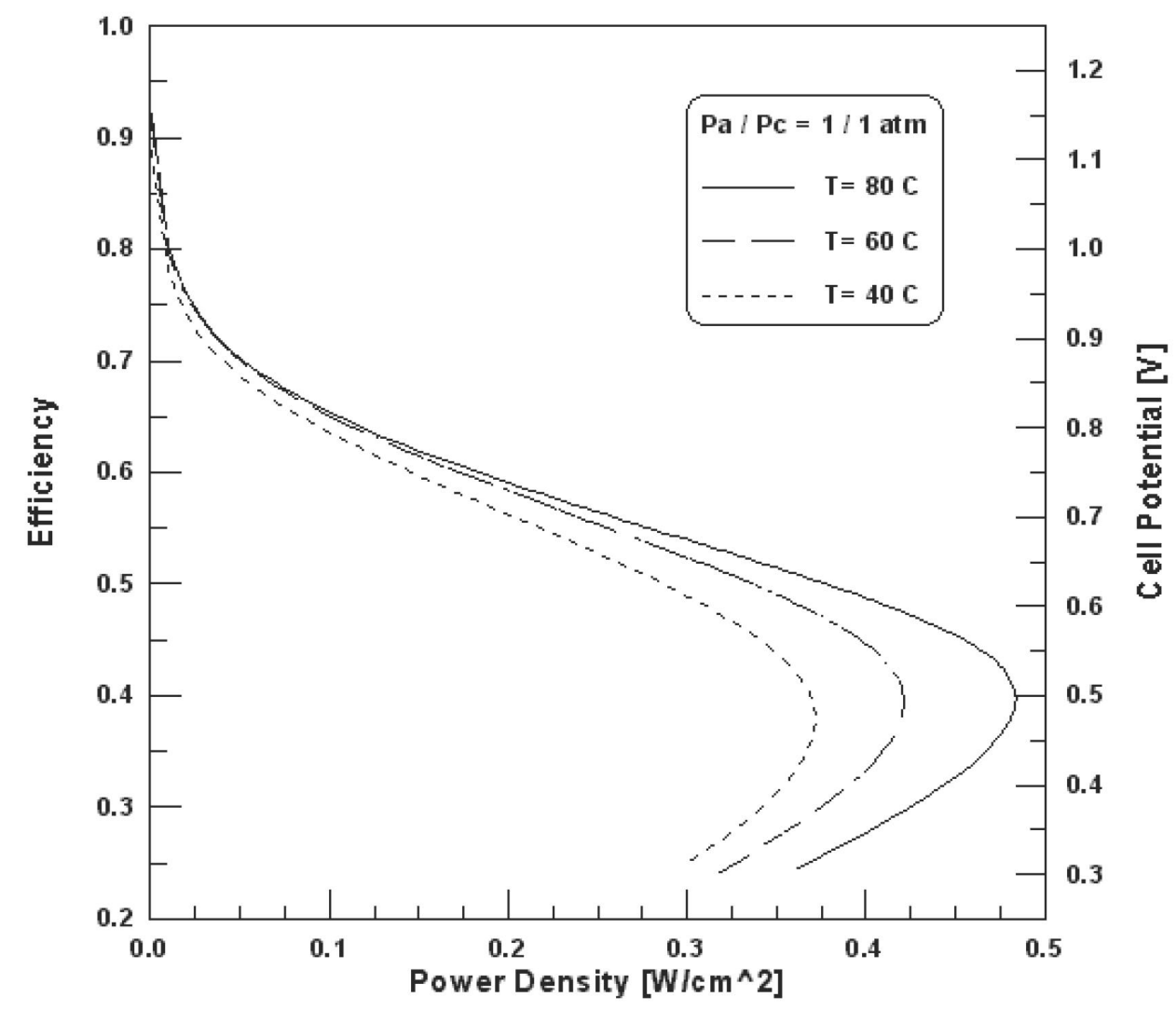

Figure 13. Relationship between fuel cell efficiency and power output [피]

Operating conditions that give optimal fuel cell performance depend on the application area [333], [34]. Stationary, portable, and transportation applications all have different requirements and operate in different environments. Usually, many compromises in the operating points (cell voltages and related current densities) of the specific cell are necessary to meet the application requirements, obtain lowest system cost, and achieve acceptable cell life. Operating points are based on defining specific system requirements, such as power level, voltage, efficiency, and system weight. It is a matter of selecting a cell operating point (cell voltage and related current density) until the system requirements are satisfied (such as lowest cost, lightest unit, and highest power density or such as highest efficiency and lowest operating cost). For example, a design point at high current density will allow a smaller cell size at lower capital cost to be used for the stack, but a lower system efficiency results (because of the lower cell voltage) and attendant higher operating cost. This type of operating point would be typified by a portable application (such as vehicle, laptop PC, or cell phone) where light weight and small volume are important drivers for cost effectiveness. Operating at a lower current density, but higher voltage (higher efficiency, and lower operating cost) would be more suitable for stationary power plant operation [35].

Figure 14 shows the relationship between the thermodynamic efficiency and the power density of the cell operates at base case conditions. In addition, the figure shows the variation of the maximum temperature gradient inside the cell with cell power density. It is clearly shown that the efficiency at maximum power is much lower than the efficiency at partial loads, which makes the fuel cells very attractive and efficient for applications with highly variable loads where most of the time the fuel cell is operated at low load and high efficiency. The cell's nominal efficiency is therefore an arbitrary value, ranging anywhere between about 0.4 and $\sim 0.7$, which can be selected for any cell based on economic rather than on physical constraints. For example, for a cell operates at base case condition, one may select a maximum operating point at $0.56 \mathrm{~V}$ and $1.25 \mathrm{~A} / \mathrm{cm} 2$, resulting in $0.7 \mathrm{~W} / \mathrm{cm} 2$ and an efficiency of 0.455 with maximum temperature gradient inside the cell of $7.9 \mathrm{~K}$. However, one may get the same power output by selecting two cells, connected in series, operating at $0.733 \mathrm{~V}$ and $0.5 \mathrm{~A} / \mathrm{cm} 2$ each. Obviously, the latter would be twice as expensive, weight, and size, but it would be more efficient (0.584), and therefore would consume less fuel. Also, the latter two series cells runs with less temperature rise inside each cell (only $2.73 \mathrm{~K}$ ), and this leads to prevent drying out of the membrane 
and excessive thermal stresses that may result in rupture of the membrane, and therefore less thermal management problems, and achieve long cell life ${ }^{[35]}$. However, since efficiency drops with increasing power density, there is a tradeoff between high power and high efficiency. Fuel cell designers must select the desired operating range according to whether efficiency or power is paramount for the given application. This example clearly illustrates that the efficiency of a fuel cell may be "bought" by adding more cells, and it is driven by economic factors, such as the cost of individual cells, cost of hydrogen and the resulting cost of generated power.

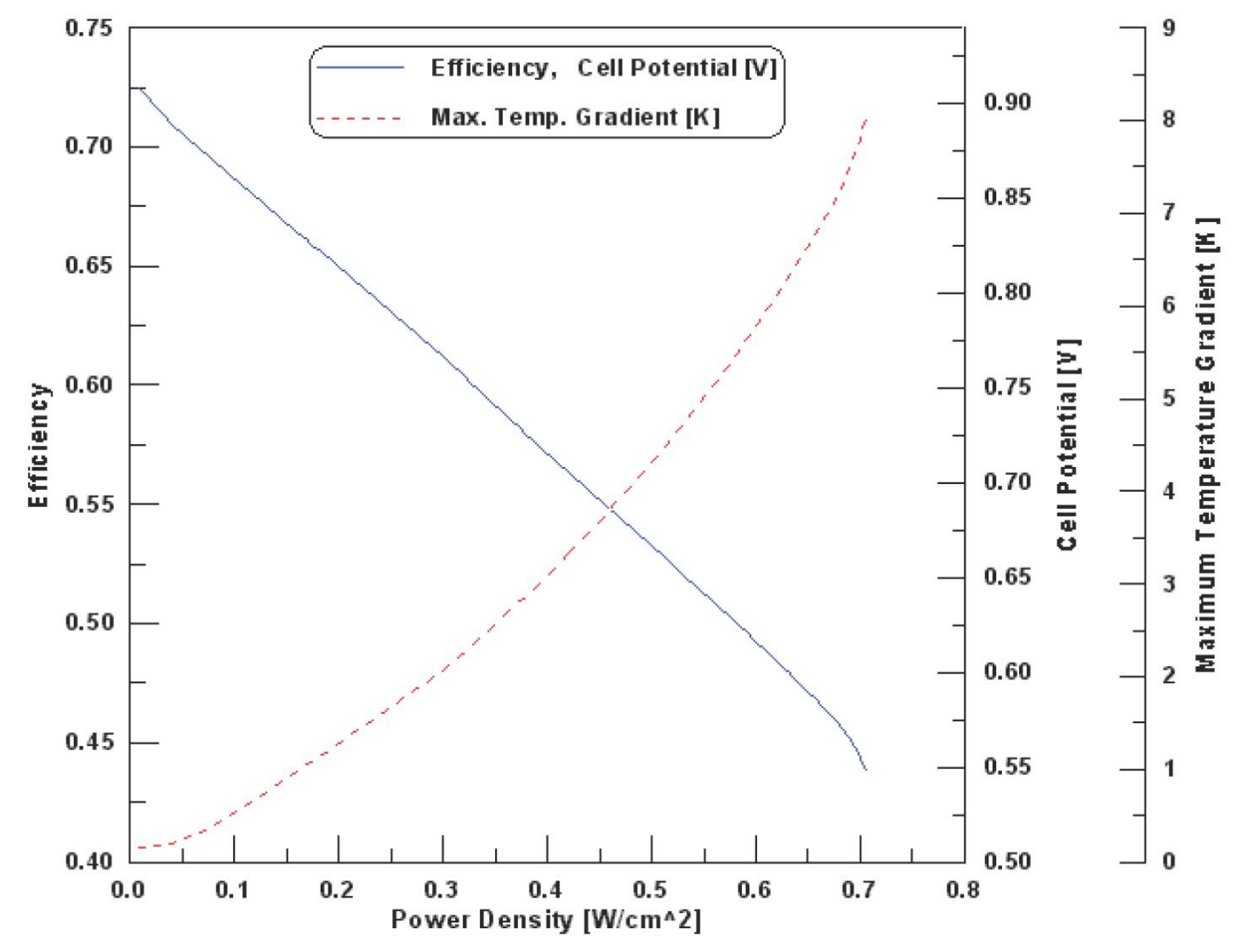

Figure 14. Relationship between the thermodynamic efficiency and the power density of the cell operates at base case conditions [프.

\section{References}

1. Maher A.R. Sadiq Al-Baghdadi. PEM FUEL CELLS - From Fundamentals to Research Studies; International Energy and Environment Foundation: ISBN-13: 9798634858883, 2020; pp. 478 pages.

2. Maher A.R. Sadiq Al-Baghdadi; Using of produced water associated with oil and gas production as a source of hydrogen: solar electrolysis cell application. Ovidius University Annals of Chemistry Journal 2009, 20, 44-47.

3. Maher A.R. Sadiq Al-Baghdadi. Hydrogen - Gasoline Fueled SI Engine Simulation; International Energy and 
Environment Foundation: ISBN-13: 9798634169286, 2020; pp. 50 pages.

4. Maher A.R. Sadiq Al-Baghdadi. Alternative Fuels Research Progress; Maher A.R. Sadiq Al-Baghdadi, Eds.; International Energy and Environment Foundation: ISBN-13: 9781484057711, 2013; pp. 442 pages.

5. Maher A.R. Sadiq Al-Baghdadi; A Simulation model for a single cylinder four-stroke spark ignition engine fueled with alternative fuels. Turkish Journal of Engineering and Environmental Sciences2006, 30, 331-350.

6. Maher A.R. Sadiq Al-Baghdadi; A study on the combustion of renewable alternative fuels in spark-ignition engines. Journal of Scientific and Engineering Research 2009, 2, 345-372.

7. Maher A.R. Sadiq Al-Baghdadi; Mechanical and thermal stresses analysis in diesel engine piston with and without different thermal coating layer on piston head. Asian Transactions on Engineering Journal 2015, 5, 6-20.

8. Maher A.R. Sadiq Al-Baghdadi; A prediction study of a spark-ignition supercharged hydrogen engine. Energy Conversion \& Management 2003, 44, 3143-3150.

9. Maher A.R. Sadiq Al-Baghdadi; Effect of compression ratio, equivalence ratio and engine speed on the performance and emission characteristics of a spark ignition engine using hydrogen as a fuel. Renewable Energy Journal 2004, 29, 2245-2260.

10. Maher A.R. Sadiq Al-Baghdadi; Development of a pre-ignition submodel for hydrogen engines. Proceedings of the I MECH ENG. Journal of Automobile Engineering 2005, 219, 1203-1212.

11. Maher A.R. Sadiq Al-Baghdadi; Measurements and predictions of pre-ignition limited operating conditions of a four stroke spark ignition engine fueled with hydrogen. Journal of Scientific and Engineering Research 2009, 2, $269-277$.

12. Maher A.R. Sadiq Al-Baghdadi; Hydrogen, the alternative fuel for internal combustion engines. Journal of Jordanian Engineer. The journal of Jordanian Union of Engineers 2005, 39, 88-99.

13. Maher A.R. Sadiq Al-Baghdadi; Study of the performance and exhaust emissions of a four-stroke spark ignition engine fuelled with hydrogen. Journal of Scientific and Engineering Research 2008, 1, 65-79.

14. Maher A.R. Sadiq Al-Baghdadi; Possibilities of improving the performance of a spark-ignition engine working with hydrogen as an alternative fuel. Journal of Scientific and Engineering Research 2009, 2, 189-196.

15. Maher A.R. Sadiq Al-Baghdadi; Simulation model for determination of composition of combustion products for spark ignition engine fueled with alternative fuels. Journal of Scientific and Engineering Research 2009, 2, $197-217$.

16. Maher A.R. Sadiq Al-Baghdadi; A prediction study of the effect of hydrogen blending on the performance and pollutants emission of a four stroke spark ignition engine. International Journal of Hydrogen Energy 1999, 24, 363375.

17. Maher A.R. Sadiq Al-Baghdadi; Measurement and prediction study of the effect of ethanol blending on the performance and pollutants emission of a four-stroke spark ignition engine. Proceedings of the I MECH ENG. Journal of Automobile Engineering 2008, 222, 859-873.

18. Maher A.R. Sadiq Al-Baghdadi; Effects of Ethanol - Gasoline Blends on Exhaust and Noise Emissions from 4-Stroke S.I. Engine. Engineering and Technology Journal 2011, 29, 1438-1450.

19. Maher A.R. Sadiq Al-Baghdadi; Ethanol as an octane enhancer for the commercial gasoline fuels. The Iraqi Journal for Mechanical and Materials Engineering 2008, 8, 96-109.

20. Maher A.R. Sadiq Al-Baghdadi; Improvement of performance and reduction of pollutant emission of a four stroke spark ignition engine fueled with hydrogen-gasoline fuel mixture. Energy Conversion \& Management 2000, 41, 7791.

21. Maher A.R. Sadiq Al-Baghdadi; Performance study of a four-stroke spark ignition engine working with both of hydrogen and ethyl alcohol as supplementary fuel. International Journal of Hydrogen Energy 2000, 25, 1005-1009.

22. Maher A.R. Sadiq Al-Baghdadi; A study on the hydrogen-ethyl alcohol dual fuel spark ignition engine. Energy Conversion \& Management 2002, 43, 199-204.

23. Maher A.R. Sadiq Al-Baghdadi; The safe operation zone of the spark ignition engine working with dual renewable supplemented fuels (hydrogen + ethyl alcohol). Renewable Energy Journal 2001, 22, 579-583.

24. Maher A.R. Sadiq Al-Baghdadi; Hydrogen-ethanol blending as an alternative fuel of spark ignition engines. Renewable Energy Journal 2003, 28, 1471-1478.

25. Maher A.R. Sadiq Al-Baghdadi; Engine performance and pollutant emission of a spark ignition engine using hydrogen-methanol blended fuels. Journal of Scientific and Engineering Research 2009, 2, 279-290.

26. Maher A.R. Sadiq Al-Baghdadi; Improvement of performance and reduction of pollutant emissions of a four-stroke spark ignition engine fuelled with a mixture of hydrogen and methane as a supplementary fuel to alcohol. Proceedings of the I MECH ENG. Journal of Automobile Engineering2004, 218, 543-548.

27. Maher A.R. Sadiq Al-Baghdadi; Prediction of performance and pollutants emission of a homogeneous charge compression ignition engine fuelled with a mixture of hydrogen and methane. Journal of Scientific and Engineering Research 2009, 2, 335-344.

28. Maher A.R. Sadiq Al-Baghdadi; Ignition control of methane fuelled homogeneous charge compression ignition engines: a parametric study. Journal of Scientific and Engineering Research 2010, 3, 83-92. 
29. Maher A.R. Sadiq Al-Baghdadi. PEM Fuel Cell Engines: Principles, Design, Modelling, and Analysis; International Energy and Environment Foundation : ISBN-13: 9781983474996,2018 ; pp. 478 pages.

30. Maher A.R. Sadiq Al-Baghdadi; Modelling of proton exchange membrane fuel cell performance based on semiempirical equations. Renewable Energy Journal 2005, 30, 1587-1599.

31. Maher A.R. Sadiq Al-Baghdadi; A simple mathematical model of performance for proton exchange membrane fuel cell. International Journal of Sustainable Energy 2007, 26, 79-90.

32. Maher A.R. Sadiq Al-Baghdadi; Optimization study of proton exchange membrane fuel cell performance. Turkish Journal of Engineering and Environmental Sciences 2005, 29, 235-240.

33. Maher A.R. Sadiq Al-Baghdadi; Modelling optimizes PEM fuel cells to extract peak energy from our fuels - a CFD study. Ovidius University Annals of Chemistry Journal 2007, 18, 31-36.

34. Maher A.R. Sadiq Al-Baghdadi; Performance Optimization of a PEM Hydrogen-Oxygen Fuel Cell. International Journal of Energy and Environment 2013, 4, 175-184.

35. Maher A.R. Sadiq Al-Baghdadi; Optimum operating point of PEM fuel cells to extract peak energy from our fuels. Fuel Cell 2007, 7, 36-38.

\section{Keywords}

Hydrogen; Alternative fuel; Fuel cell; Internal combustion engines; Clean energy 